\title{
From the Editor:
}

In the Summer, 1984 issue of the Bulletin we included four "Short Papers" and in this current issue we have seven papers. This is very encouraging, but as of the moment (February, 1985) I have not received any papers for the Summer, 1985 issue. Let me, therefore, issue yet another call for short papers. I would appreciate hearing from any of you who intend to submit papers for the Bulletin during the coming year.

William O. Thweatt Editor 